\title{
WOULD BE SMART BALINESE CITIES (INDONESIA): AN EXPLORATORY CASE STUDY
}

Somayya Madakam https://orcid.org/0000-0001-6708-2061

FORE School of Management, New Delhi, India.

\section{ABSTRACT}

The word "Smart Cities" is the new buzzword in every corner of the world. Many countries across the continents are trying to plant new smart cities or in the conversion process of existing cities. Bali (Indonesia) also seems to be in a conversion process of its Brown Field Cities. This research manuscript attempts to explore the Bali (Island) as a Smart Island regarding Smart Environment, Smart Economy, Smart Governance, Smart Mobility, Smart Living and Smart People dimensional perspective. This research manuscript has adopted a triangulation method for thematic narration since the study is qualitative and case study. The study explored that still Bali/Balinese cities is/are still baby stepping of smart cities plantations. There needs to be lot of work has to be done to become Smart Bali Island. The findings will help the Bali government to understand how far they could become full-fledged Smart Island by providing the Quality of Life to citizens and economic development of Bali.

Keywords: Bali, Indonesia, Smart City, Smart Tourism, Quality of Life .

Manuscript first received: 2019/02/19. Manuscript accepted: 2019/12/07

Address for correspondence: Somayya Madakam, FORE School of Management, New Delhi, India.

E-mail: somayya@fsm.ac.in 


\section{INTRODUCTION}

For the author, it was the first Faculty Development Programme (FDP) by the FORE School of Management, New Delhi, organized outside India at Bali, Indonesia. It was so curious, anxiety, and interesting because the author loves to travel foreign countries and try to understand the culture, customs, socio-economic and developmental conditions of that particular country along with the technological deployment penetration in their day-to-day life. The author was waiting for almost six months since author's joining from the Institute. There were many informal discussions about FDP during those six months. Initially, it was planned for Colombo and Kandy (Sri Lanka: Formerly Ceylon is an island nation south of India in the Indian Ocean), but it got changed to Bali (Indonesia) due to several reasons. Finally, the day has come. It was $21^{\text {st }}$, September 2018. The faculty from FORE in toto 31 including one administrative officer and author reached the Indira Gandhi International Airport New Delhi, by $8.30 \mathrm{pm}$. The flight took off at $10.05 \mathrm{pm}$ and transit flight from Kuala Lumpur (Malaysia) at $7.35 \mathrm{am}$ in the next day and finally reached to the destination, Bali (Indonesia) at 10.45 am through Malindo Airways, Malindo Airways Sdn Bhd is a Malaysian full-service airline. The Airways is owned by Indonesian Lion Air Group with headquarters in Petaling Jaya, Selangor, and Malaysia. Of course, the faculty - FDP, outside India, was a thought process of FORE School of Management' President. It believes that the international exposure to the faculty will definitely a good platform, where they do different learnings about one country and understand the development of science and technology, social, economic expansions and especially the cultural dimensions, traditions, and customs etc. most importantly, faculty can understand the how different business dimensions in terms of marketing strategies, supply chain operations, managing the projects, IT/ ITeS, financial services and effective utilization of HR practices in the companies, can have a practice of international business physiognomics.

\section{LITERATURE}

Cities have a significant impact on the economic and social development of any nation. They are genuine platforms where people live, work, learn, and play, they are where companies have their business and in which numerous services are provided to the urban citizens. We are all so familiar with poor public transportation facilities and low quality of roads, which are leading to the traffic congestion, increase in accidents, higher $\mathrm{CO}_{2}$ emissions, and many more health issues. The electrical power and potable water shortages are a part and parcel of every urban citizen's life, be it due to poor quality equipment, broken pipes, faulty meters, grid failure, or something else. Like these urban issues are innumerable, which is negatively impacting the overall Quality of Life (QoL) of Indian citizens by increasing their complexities, expenses and decreasing their efficiency. To accommodate this massive urbanization, cities needs to find smarter ways to manage complexities, reduce expenses, increase efficiencies and improve the Quality of Life. This can be achieved through deployment of Internet of Things (IoT) technologies in existing brownfield cities or building new Smart Cities.

"Smart Cities" is the new catchword in every corner of the world. Even though a huge amount of literature poured in recent 5-8 years on Smart Cities, the phenomenon has roots since 1992. That means the urban places including common people, government, municipality servants started recording their city-related information. Initially, they used to store urban citizen's date of birth, date of death, their 
demographic information, employment, plus other household related data, land records, tax payments, and electricity and water bills through the computer and other electronic computational devices. Now the urban governments reached to such a stage where they can completely be coming with new urban solutions like all the citizen services plus the roads, houses, building a structure using designed using Geographical Information Systems. Vehicles are moving with Geographical Position Systems technology, tagging with electronic nameplate for better toll operations and smart parking facilities. Even lakes, mountains, trees and animals in the forest are tagging by RFID for unique identification. That means the smart cities are new constructions for better urban identity, city operations, with improved facilities by marrying with advanced technologies. This will ultimately lead to improving urban citizen's life. This connote is not only limited to India, South Korea, or Saudi Arabia, but also to the cities, countries and even continents and striving for building these new advanced technological urban structure. Their main motto is to provide Quality of Life to the residential people, plus balance ecological system and finally improve the economy of the cities, states, and finally nations. Indonesia has also planned to achieve 100 smart cities in 2019 and 514 cities in 2025, The name of this plan is "Movement to 100 Smart City", which was established in 2017 by Ministry of Communication and Informatics in cooperation with Ministry of Internal Affairs, Bappenas, Minister for Public Works and Human Settlements and Presidency. Some cities in Indonesia, which have doing to be smart city by initiated quick win program including Tangerang, Bandung, Banyuwangi, Siak, Pelalawan, Banyuasin, Jambi, Tangerang, Bekasi, Bogor, Sukabumi, Cirebon, Semarang, Sleman, Bojonegoro, Sidoarjo, Gresik, Samarinda, Tomohon, Banyuwangi, and many more (Handoko, 2018). However, developments such as smart cities, infrastructure projects such as Palapa Ring Project and the rise of FinTech firms could see the digital economy take off sooner (Paul, 2018).

\section{OBJECTIVES}

To understand the Balinese Cities as a Smart Cities dimensional phenomenon concerning smart economy, smart environment, smart governance, smart living, smart mobility, and smart people

\section{RESEARCH METHODOLOGY}

Research methodology is the systematic way of the study of research methods, used while right from the beginning of identifying problem, defining objects, data collection, analysis, and interpretations by the researcher about a particular phenomenon. The Data collection in this study was conducted mainly through the triangulation method about the phenomenon, which means empirically confirmed via more than two data collection methods.

\section{Observation}

According to Marshall and Rossman (1989) observation, the systematic description of events, behaviors, and artifacts in the social setting chosen for study. The observation methods exist since research started, it is the best method specifically used in life sciences, chemical, physical sciences, and some of the also social sciences phenomenal evidence. The author did specifically non-participatory observation. The entire observation process carried out only for three days and that was done from the period 22/9/2018 to 24/9/2018 as a part of Faculty Development Program (FDP) at Bali, Indonesia. 


\section{Expert Presentations (In-depth Interview)}

The second method used to confirm the Balinese cities phenomenon characteristic was through expert presentations basically about Bali Island and Indonesia as a whole country. The expert's presentations are considered due well, versed with Balinese cities and Indonesia circa more than 40 years with their own experience. They were born and brought up in the same country, highly educated, working for the development of their nation. So they knew the physiognomies of both Bali Island and Indonesia thoroughly.

\section{Secondary Data}

Under being archived and made available any primary data can serve as secondary data for others. The secondary data is predominately contributing to research in this technological arena. The beauty of this methodology is that the investigator need not travel to the observational places. The data is freely available 24/7 / based on subscription. This method takes out all the barriers like location access plus best testimony from the observer point of view. This method is used for the support of expert presentations data and the author's non-participatory observation. Off course the data was accessed during 1-9-2018 to 30-9-2018 from different search engines like mamma, google, google scholar and Mozilla Firefox by mining of the databases EBSCO, KNIMBUS, Web of Science and Scopus.

\section{Sample Size}

For any research, the sample size is an important parameter, in which the commonality of the behavior of the phenomenon is decided by the sample size only. However, as per the literature, the study falls using a single case study method, in which there is no much sample size is required. The size was consisting of four respondents along with observation and online secondary data collection support for the mono case description. The sample names include the experts from Indonesia specifically the presenters.

- Ms. Astiti Suhirman, Technical Adviser - Kantar-TNS, Jakarta (Indonesia)

- Dr. Teguh Dartanto, Faculty of Economics and Business, Universitas Indonesia, Campus

- UI Depok

- Dr. Manuati Dewi, Faculty of Economics and Business, Udayana University, Bali

- Mr. Sive - Tourist Guide, Bali (Indonesia)

- Observation (Non-Participatory)

- Reports, Tourism Guide Tracks, Research Papers, Blogs 


\section{Observation Area}

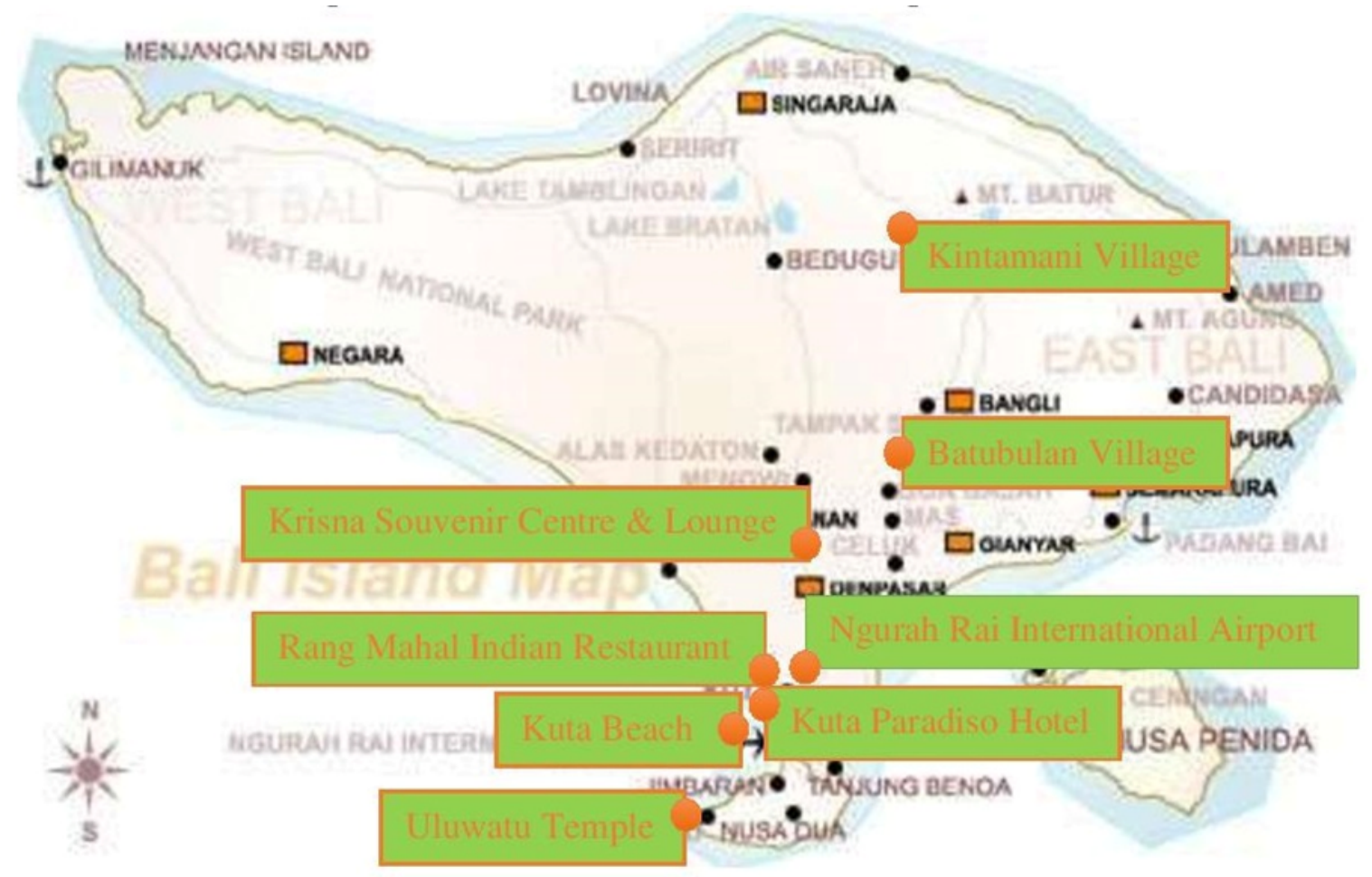

Figure 1. Bali Island Map: Observation Area

Source: https://www.exoticbalitravel.com/info/mapbali.html

\section{Data - Analysis}

Case study analysis generally involves an iterative, spiraling or cyclical process that proceeds from more general to more specific observations (Cresswell, 1998; Palys,1997; Silverman, 2000). Since the study is a single case study, with the help of the triangulation method, thematic coding was done under a descriptive analysis. Importantly the study looked at Balinese Cities as a smart city - six dimensions' perspective i.e. smart economy, smart environment, smart governance, smart mobility, smart people, and smart living stated by Giffinger et al., (2007). The authors tried to find out the important codes like economic, technology, environmental, and quality life factors in aligned with smart cities dimensions. The authors also tried to scribble how the tourism industry is backing to economy of the Bali Island as well as Indonesia. With this, the case study tried to understand how Bali Island is trying to become the Smart through its new tourism and technological deployment mechanism implementations in different city dimensions. The data was in the text (portable document formats: research articles) format, power points presentation form, and research notes during the observation period. The videos and pictures captured by the Sony - high configuration mobile were also the base for supporting the scripting of this case study (Smart Bali, Island). The in-depth narrations by presenters and observational notes. The academic, business and research presentation data on Bali and Indonesia included the themes of (1) Do you know Indonesia -Quiz? Indonesia Consumer Culture and Trends (2) Economic Growth and Growth inclusiveness in Indonesia and (3) Organizational Culture and Leadership in Indonesia are supported. 


\section{CASE STUDY - DESCRIPTION}

It was not only limited to the conversion of Brown Field Cities into Smart Cities like HongKong, Shanghai, New-York, Paris, London, New Delhi across the globe but also to one of the South Asian cities, Balinese Cities (Bali) also. These cities are trying to bring the Quality of Life to all citizens who are residing in that particular city including tourists. The Smart Cities definition varies from cities to cities. Some cities across the world working towards eco-system oriented, some of them are boosting the financial services, some cities are backing the tourism, and some of them are trying to increase the Quality of Life of city dwellers. Besides most of the cities are promoting the Smart Cities for economic development. Where ever it may be the city, the ultimate conversion from the existing normal metropolitan city into Smart City is basically for improving the Quality of Life of the citizens, boosting the economy of the city as well as the nation and finally to protect the environment for the future generations. This research manuscript will look at the smart city dimensions of the Balinese cities specifically tourism perspective. From the literature we knew that a smart city consists different dimensions, however, the best spoken smart cities in the literature by Rudolf et al., (2007), with six dimensions of smart economy, smart environment, smart mobility, smart living, smart people, and smart governance. Let us try to understand how Balinese cities (Bali) are fulfilling this six dimensions' criterion in order to provide Quality of Life to its citizens. The Internet of Things technology is base for Quality of Life. Initially, it was defined that citizens should have good health conditions and then followed by sound economic conditions along with financial security. Later some of the research studies well suggested that the Quality of Life can be possible with the help of individual psychology too. Now recent studies stressing on the collective indicators of social, economic, health, psychological and most importantly the recent advanced technology deployment in our daily actives can collectively cause Quality of Life. The Quality of Life has gained prominent attention in human services over the last 20 years (Sheppard et al., 2005).

\section{Smart Economy}

Smart Cities generally base their strategy on the use of Information and Communication Technologies in several fields including the economy (Bak1c1, et al., 2013). It was known that the economy is an indicator of the development of any city/state/country. Way back in the 1970s, the Balinese economy was largely agriculture-based in terms of output and employment. Now the backbone of Bali's economy is mostly on tourism. Tourism is the largest single industry regarding income, and as a result, Bali is one of Indonesia's wealthiest regions. In 2003, around 80\% of Bali's economy was tourism related. Bali is a popular tourist destination, which has seen a significant rise in tourists since the 1980s. Tourism-related business makes up 80\% of its economy (Vickers, 2013). As per [2] Desperately Seeking Survival Time (2002), it is renowned for its highly developed arts [traditional and modern dance, sculpture, painting, leather, metalworking, and music]. That means the best business model to increase the Bali's economy is Tourism. They are also doing by encouraging hotel services and better security mechanisms for tourists. Collaborations with other counties which can help to improve their mining business to the external world. Encouraging the inflow Foreign Direct Investments (FDI) from various countries, financial institutions. The author also found that that there is a gigantic offshore business [via IT/ITeS] inflow to Bali from across the globe. This 
is causing to plant new business models at the different parts of the Bali Island. The plus point of Balinese cities' economic push is carbon-free business models. Thus Bali is boosting its economy by its smart tourism business model in which tourism is technologically supported for convenience.

\section{Smart Environment}

According to a survey in 2002 by National Institute of Aeronautics and Space (LAPAN), the Indonesian archipelago has 18,307 islands, and according to the CIA World Fact book, there are 17,508 islands. Out of these, only 922 of those permanently inhabited and out of which the Bali island area is $5,780 \mathrm{~km}$. However, the nature in the Bali island is fully enriched with dense forests, volcanic mountains, seashores, planned cultivated land specifically iconic rice paddies, coral reefs, and concrete jungles. This island is so beautiful that in an exaggeration, people even call it "The Island of the Gods" like "The God's Own Country", Kerala State (India). The complete island is surrounded by Indian ocean almost in the south-west, and Bali sea on the north-east sides. Because of its natural beauty, and tourism attractively, people across the globe prefer to travel to Bali for their vacations, weekends and leisure period. Unfortunately, the Bali bombings occurred on 12 October 2002 in the tourist district of Kuta, the prime location of Bali on the Indonesian island. Hence, over some time, this had drastically reduced the tourists from different countries to not only to Kuta, and other Balinese cities, and entire Indonesians islands. Besides, the Mount Agung, in Bali's northeast volcano sent huge plumes of ash into the air for two days late December 2017 - temporarily closing the island's Ngurah Rai International Airport. This will also be caused the tourism diminishing to Bali Island. Later Bali tourism government had taken a lot of security mechanisms initiatives at the immigration to tourists in Denpasar International Airport. Besides, the city police do 24/7 patrolling to prohibit the human made disasters specifically terrorist attacks. They are more concern about tourist's security and hence deployed various technological monitoring systems in public places like CCTV and IP Cameras all public places. As a part of better ecosystems, they are trying to manufacture ecofriendly products and services in order to protect the environment.

Nowadays the residential houses, offices and services industries trying to deploy the latest technologies in which auto-identification of people, automation of process industries, events monitoring and controlling of human-made and natural disasters warnings to citizens through automated alert systems. Hoping that in the future the Bali citizens can be protected from volcano eruptions, and tsunami-like which were happened in 2010 Mentawai earthquake occurred with a moment magnitude of 7.7 on 25 October off the western coast of Sumatra at 21:42 local time. Expecting that the Bali fully take prevention mechanisms from both human made/natural disasters with advanced technologies deployment in respected risky places by getting warning signals before a disaster takes place. New technology like drones and satellites have allowed to more clearly see what is happening where we could not before, and these new data can help volcanologists better understand what a volcano might be doing next (Erik, 2017). Smart Environments augmented with computational resources that provide information and services when and where desired (Abowd and Mynatt, 2004). Because of its natural beauty in entire Balinese cities/Island as shown in Figure 2., the entire world is attracting for tourism. 


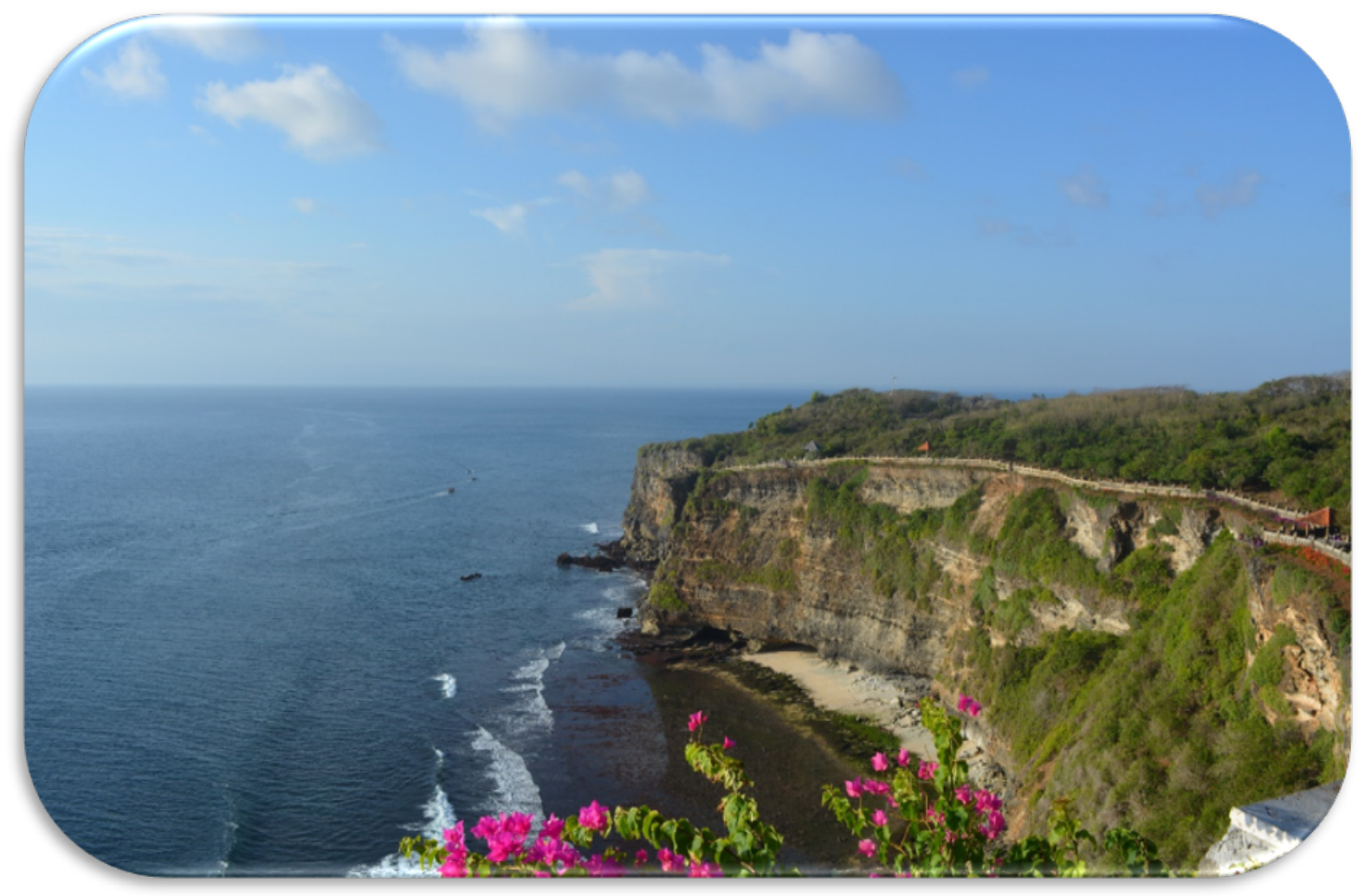

Figure 2. Bali Natural Environment

Source: Author's

\section{Smart Mobility}

On March 2017, the TripAdvisor named Bali as the world's top most destination in its Traveller's Choice award [1]. That means many visitors prefer Bali visit to see many natural, beautiful and good places. The best part of the Bali is the International accessibility via International Airport, Denspara (The capital city of Bali), which is completely modernized city like other global international airports. However, while coming to good transportation is lacking specifically like public bus transportation. The individual' two wheelers, four wheelers, and private taxis are more comfortable to do journey from the west -to- east and north -to- south of Bali island in even one day. Off course, this mobility mechanism may not be work for the visitors. Because of the geographical area of this island is very less, there would not be any requirement for public transportation. However, the government has to look at public transport systems like bus transportation, metro trains in the Island for the better, healthy, joyful journeys in the Bali. So in this scenario, the Bali government has to look at the better smart mobility mechanisms on a par with other developing cities to sustain in the competitive tourism. Most of the tourist are from Western Australia, China, Europe, India, Japan and few people from the rest of the world. The other reason tourists floating in Bali is economically very cheap for other nations. The Smart Tourism Destinations concept emerges from the development of Smart Cities. With technology being embedded on all organizations, destinations will exploit synergies between ubiquitous sensing technology and their social components to support the enrichment of tourist experiences (Buhalis 
\& Amaranggana, 2013). There is a study also on stress on Indicators to measure smart mobility: An Indonesian perspective by Aini \& Amani, (2017). This means the importance of Smart Mobility is started across the globe. Because of international tourism attractively, the International Accessibility - Bali's I Gusti Ngurah Rai Airport is completely modernised, this can be figured out from Figure 3.

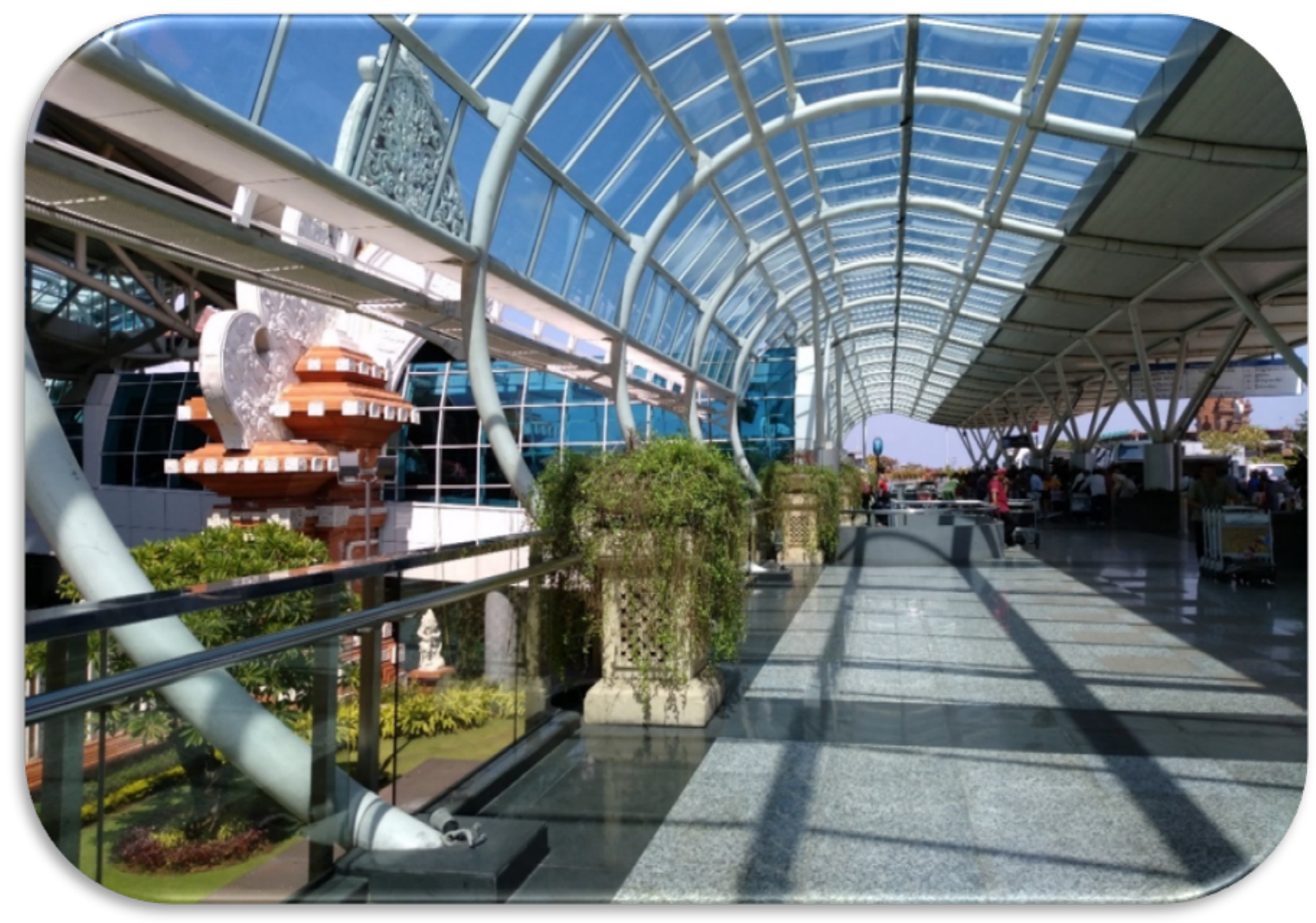

Figure 3. International Accessibility - Bali’s I Gusti Ngurah Rai Airport

Source: Author's

\section{Smart Living}

Smart Living is gradually changing people's life (Yan \& Shi, 2013). The vision of smart living promises innovative services from providers in the energy, healthcare, entertainment, and surveillance sectors (Nikayin et al., 2011). However, some of the academic literature say that Smart Living is to compile several aspects that substantially improve the quality of life of citizens, such as culture, health, safety, housing, and tourism, etc. (Mishra, 2013). It is more about the living places and surrounding environments to the city citizens. In the same line the city of Bali trying to deploy the Smart Living practices in all city dimensions. The world knows that the Kuta place in Bali is well known for its beach, LIPPO mall, Discovery shopping mall, banks, money exchanges, good restaurants, art market, souvenir shops and Legian street for Night Live area. These are the places anybody prepares to enjoy and willing to stay for some time. All the residential and dwelling places are fully deployed with the latest IoT technologies at respected places in buildings in order to identify the people, and objects. 
There are automated technologies used or installed at the process level completion. All the homes and buildings are aesthetically designed in the entire city; it seems it falls under one of the 21 st-century cities

\section{Smart Governance}

The rules, regulations, schemes, public funds, social and physical infrastructure are important needles of the economy of the cities and countries. So governance is one of the main indicators of any town, city, state and national performance to provide these. However, these are all existing practices in all cities throughout the globe. Now all the governments are transforming from governance-to-good governance and good governance-to-e-governance and finally trying to implement smart governance practices. The smart governance practices will bring transformational development even to a common man. These practices will bring people and government brainstorming - to societal developments. The crowdsourcing by the citizens one of the practices. They used fully advanced technologies to give services. The Bali is also trying to bring better leadership practices like the transformation of societies via charismatic leadership practices. The leaders are working to the last mile citizens of the country. Trying to bring the citizen services round the clock through smart governance practices. The leaders in picture 4 is a good example. All the government organizations are trying to deploy the latest Information Technology /IT enabled services products and services in order to provide citizen services across the Bali Island. The government is trying to practice crowdsourcing techniques too which will resolve common man's day to day issues.

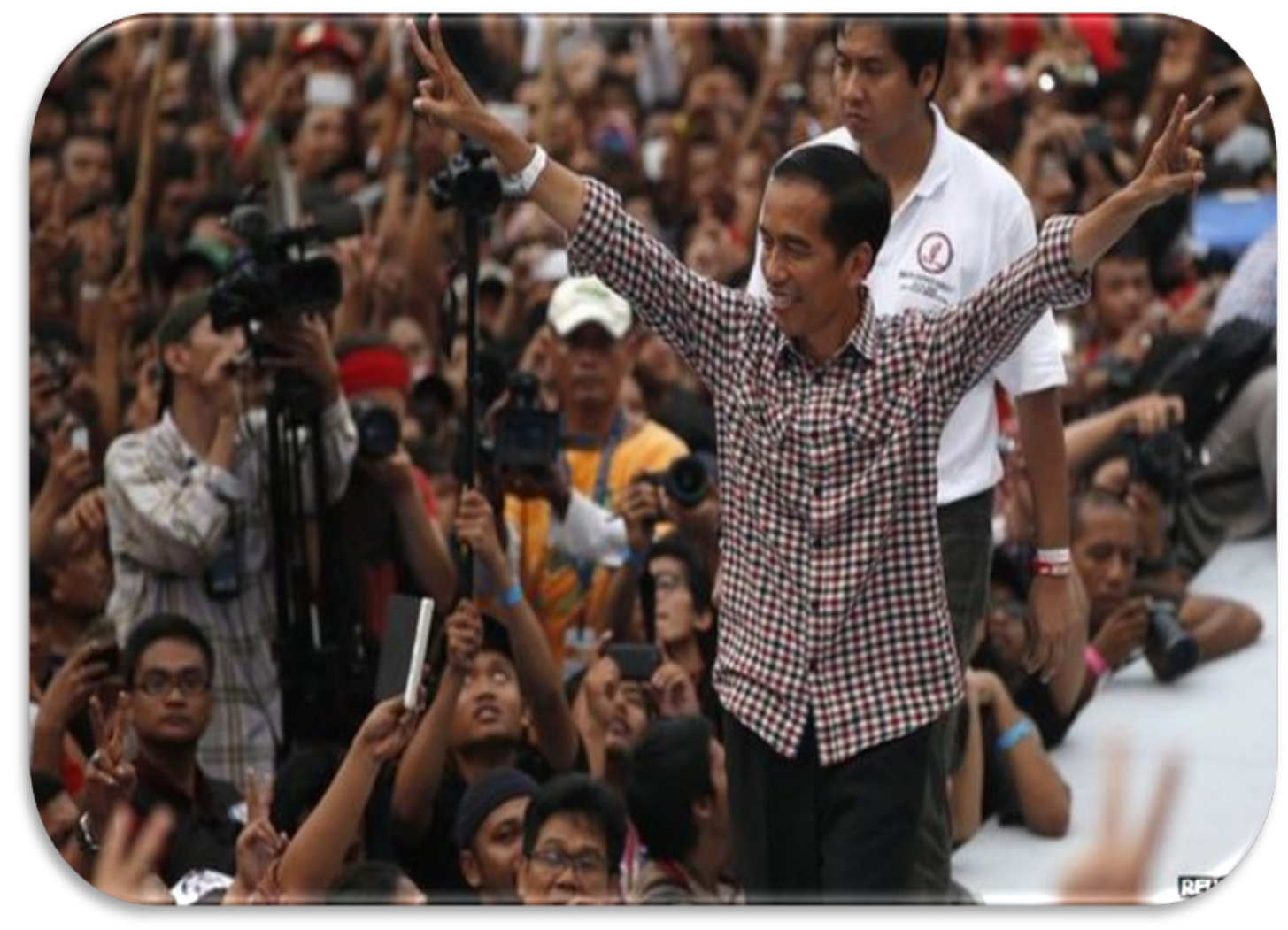

Figure 4. Transformational Leadership by Joko Widodo (Jokowi)

Source: https://philnews.ph/2014/07/23/jakarta-gov-joko-widodo-wins-indonesias-presidential-election/ 


\section{Smart People}

Balinese population is approximately 4.2 million and well enough literacy. Smart people are the most critical resource for any economy (Florida, 1999). As the authors Madakam \& Ramaswamy (2014) prescribed the physiognomies of smart people in their research paper, most of the Bali citizens are having a minimum education $(6+3+3)$. The Bali people are really smart. The Balinese are an Austronesian ethnic group native to the Indonesian island of Bali. As the literature suggests the smart people as being central to the operation of any smart city (Meijer \& Bolívar, 2016), they are always ready to learn new technologies for their better life. Most of the citizens are mobile users and self-learners from different e-learning platforms. Good amount of citizens on this island are already connected to social media through Facebook, WhatsApp, Instagram, LinkedIn and many more social media network plat-forms. They have very good social cohesion. They are habituated to cosmopolitan life. Like other metropolitan citizens, these are also open-minded. The people are so enthusiasm for lifelong learning. They have a very good adopting capability of any nations' culture, custom, technology, product, and even the food habits. Of course, they keep their values, traditions, customs, belief system too. Their organizational leadership, work environment, and embedded religious spiritual life completely a different style of work-life from the entire world. The WOW culture: The act of working, living, breathing in a way where's people's reaction to interacting with is called "WOW". This is the different phenomenon in Bali's organizations. Though the Bali is multi-religious, consisting of Christian, Muslim, and Buddhist minorities, the predominant religion is Hinduism. Balinese Hinduism, called Agama Hindu Dharma, originated from Java and is a blend of Shivaism and Buddhism. They have good faith in Hindu Gods' Vishnu, Brahma, and Maheswara. The Mahabharata and Bhagavad Gita are their religious scriptures. That is why, the Ganesh picture is inscribed on 20,000-rupee currency in Indonesia. They are converting all the latest technologies in their local language, which can easily adapt instantly.

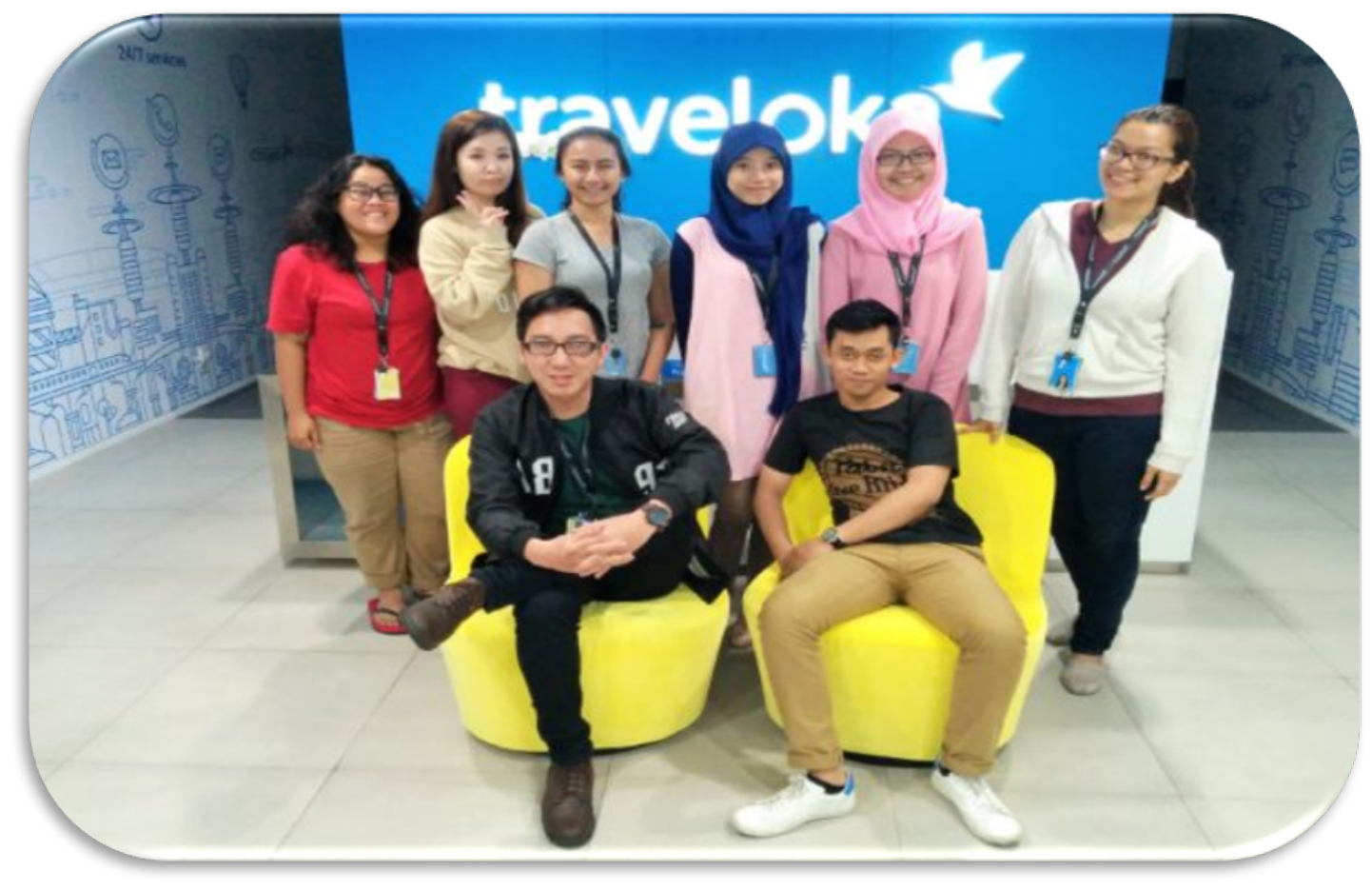

Figure 5. English Course for Employees in Bali: Life Long Learning

Source: https://www.english-today-bali.com/english-course-employees-bali-2/?lang=en 


\section{CONCLUSION}

This is a single case study, which explores the Balinese cities concerning Smart Cities - Six Dimensions. The study explored the Balinese economic, environmental, governmental, transportation, living and people perspective along with geographical descriptions. The nature of this research is qualitative. So we cannot have generalizations from these findings, except understanding the Bali Island phenomenon in relations to smart cities' 360-degree view. This study will help to understand moderately that how far the Bali is in terms of the smart cities conversion process and what kind of additional mechanisms to be adopted in order to become full-fledged Smart City. The government of Bali needs to work more towards smart cities practices of how the rest of the world is deploying the technologies in existing gaps. Bali/Balinese cities is/are still baby stepping of smart cities plantations. Hoping that in the future the Island of Bali will become more sustainable Smart Tourism City.

\section{REFERENCES}

Abowd, G. D., \& Mynatt, E. D. (2004). Designing for the human experience in smart environments. Smart environments: technologies, protocols, and applications, 151-174.

Aini, N. N., \& Amani, H. (2017, October). Indicators to measure smart mobility: An Indonesian perspective. In Proceedings of the 2017 International Conference on Telecommunications and Communication Engineering (pp. 81-85). ACM.

Bakıc1, T., Almirall, E., \& Wareham, J. (2013). A smart city initiative: the case of Barcelona. Journal of the Knowledge Economy, 4(2), 135-148.

Bali named as best destination in the world by TripAdvisor. Nzherald.co.nz. March 22, 2017. https://www. nzherald.co.nz/travel/news/article.cfm?c_id=7\&objectid=11823142. Retrieved September 25, 2018.

Buhalis, D., \& Amaranggana, A. (2013). Smart tourism destinations. In Information and communication technologies in tourism 2014. Springer, Cham.

Creswell, John (1998). Qualitative Inquiry and Research Design: Choosing among Five Traditions Oaks, CA. Thousand: Sage.

Desperately Seeking Survival Time (25 November, 2002). http://content.time.com/time/magazine/ article/0,9171,393799,00.html. Accessed on 26/9/2018.

Erik Klemetti (December 14, 2017). Peering into Erupting Volcanoes Is a Real Challenge. http://blogs. discovermagazine.com/rockyplanet/2017/12/14/peering-into-erupting-volcanoes/\#.w6touwgzbiu. Accessed on 26/9/2018.

Florida, R. (1999). The role of the university: leveraging talent, not technology. Issues in science and technology, 15(4), 67-73.

Giffinger, R., Fertner, C., Kramar, H., \& Meijers, E. (2007). City-ranking of European medium-sized cities. Vienna: Cent. Reg. Sci., 1-12.

Handoko Putra, Yeffry. (2018). Developing IT Master Plan for Smart City in Indonesia. International Conference on Informatics Engineering, Science and Technology, Bandung, Indonesia. 
Madakam, S., \& Ramaswamy, R. (2014). Smart Cities-Six Dimensions. In International Conference on Advances in Computing and Information Technology-ACIT (pp. 38-41).

Marshall, C. \& Rossman, G. B. (1995). Designing Qualitative Research, Newbury Park, CA: Sage.

Meijer, A., \& Bolívar, M. P. R. (2016). Governing the smart city: a review of the literature on smart urban governance. International Review of Administrative Sciences, 82(2), 392-408.

Mishra, M. K. (2013). Role of Technology in Smart Governance: 'Smart City, Safe City'.

Nikayin, F., Skournetou, D., \& De Reuver, M. (2011, June). Establishing a common service platform for smart living: Challenges and a research agenda. In International Conference on Smart Homes and Health Telematics (pp. 251-255). Springer, Berlin, Heidelberg.

Palys, T. (1997). Research decisions: Quantitative and qualitative perspectives. (2nd ed.). Toronto, Ontario, Canada: Harcourt Brace Jovanovich.

Paul Mah (2018). The shape of smart cities in Indonesia. Yudho Giri Sucahyo of University of Indonesia talks about the country's digital future. https://www.datacenterdynamics.com/analysis/the-shape-of-smartcities-in-indonesia/Accessed on 20/1/2019

Rudolf, G., Fertner, C., Kramar, H., Kalasek, R., Pichler-Milanovic, N., \& Meijers, E. (2007). Smart CitiesRanking of European Medium-Sized Cities. Rapport Technique, Vienna Centre of Regional Science.

Sheppard-Jones, K., Prout, H. T., \& Kleinert, H. (2005). Quality of life dimensions for adults with developmental disabilities: A comparative study. Mental Retardation, 43(4), 281-291.

Silverman, D. (2000). Doing qualitative research: A practical handbook. Thousand Oaks, CA: Sage.

Vickers, Adrian (2013-08-13). Bali: A Paradise Created. Tuttle Publishing.

Yan, M., \& Shi, H. (2013). Smart living using Bluetooth-based Android smartphone. International Journal of Wireless \& Mobile Networks, 5(1), 65. 


\section{ERRATUM}

Erratum of article: Madakam, Somayya. (2020). An Exploratory Case Study: Would Be Smart Balinese Cities (Indonesia). JISTEM - Journal of Information Systems and Technology Managements, 17, e202017005. doi 10.4301/s1807-1775202017005

In the page 1 , TITLE:

where it reads:

AN EXPLORATORY CASE STUDY:

WOULD BE SMART BALINESE CITIES (INDONESIA)

should read:

WOULD BE SMART BALINESE CITIES (INDONESIA):

AN EXPLORATORY CASE STUDY 